\title{
Comparative Study of Antioxidant Activity in Fresh and Pasteurized Goat Milk
}

\author{
Sanda ANDRE ${ }^{1 *}$, Andrea BUNEA ${ }^{1}$, Adela PINTEA ${ }^{1}$, Sorana MATEI ${ }^{1}$, Ana Maria COZMA ${ }^{2}$ \\ ${ }^{1}$ Department of Biochemistry, University of Agricultural Sciences and Veterinary Medicine Cluj-Napoca, \\ Romania \\ ${ }^{2}$ Department of Environmental Chemistry and Hygiene, «Iuliu Hatieganu» University of Medicine and \\ Pharmacy, Cluj-Napoca, Romania \\ *Corresponding author: sandrei@usamvcluj.ro
}

Bulletin UASVM Veterinary Medicine 72(2) / 2015,

Print ISSN 1843-5270; Electronic ISSN 1843-5378

DOI:10.15835/buasvmcn-vm: 11450

\begin{abstract}
The enzymatic activity of milk decreases after different heat treatments, because of two effects: the thermal degradation of the antioxidants, and the formation of new species of oxygen after the heating of the milk. The purpose of this study was to determine how the thermal processing of goat milk influences the profile of enzymatic and non-enzymatic antioxidants, caseins concentration and the concentration of malonildialdehyde (MDA, marker of lipids peroxidation). Measurements were conducted on 12 samples of fresh goat milk collected (during) over the period of two weeks. An aliquot of each sample was subjected to pasteurization. Half of all the samples were subjected to freeze-drying. The parameters analyzed for each sample were vitamins A and E; lactoperoxidase and glutathione peroxidase activity; vitamin C; total caseins; MDA.

Goat milk pasteurization causes a decrease in the concentration of antioxidant vitamins and antioxidant enzymes activities, correlated with a significant increase in the concentration of malonildyaldehide. In the pasteurized milk, changes were highlighted in the profile of caseins.
\end{abstract}

Keywords: antioxidants, caseins, goat, lipid peroxidation, milk

\section{INTRODUCTION}

The chemical composition of milk varies by species, breed, individuals of the same species, age, diet, health of the animal, environmental conditions and the growing season, during lactation, etc. (Andrei and Groza, 2010).

Goat milk compared to cow's milk is characterized by better digestibility of lipids (which appear as small cells, so more digestible) and contains double the amount of short and medium chain triglycerides. Regarding the specific proteins of goat milk, they are similar to cow's milk, from the point of view of digestibility, with a high proportion (about $80 \%$ ) of caseins. It is noted that goats have the ability to transform all carotenoid pigments into vitamin A (all carotenoid pigments), so goat milk is high in this vitamin, with approximately $30 \%$ more compared to cow's milk. That is also why the goat milk is white, compared to cow's milk, that has a yellowish white color, because the latter contains carotenoids (Banu et al., 2007).

The purpose of this study was to assess how the processes of milk pasteurization influences, on one hand, the activity of the antioxidant enzymes and the content of the antioxidant vitamins and, on the other hand, induces the lipid peroxidation processes. We have monitored the antioxidant activity of the milk by determining the activity of antioxidant enzymes lactoperoxidase (LPx) and glutathione peroxidase (GPx), and analyzed the concentration of antioxidant vitamins (vitamin 
A, vitamin $\mathrm{E}$ and vitamin C). Because many literature data showed that the main proteins in milk (caseins) have a secondary function of antioxidants, in the present study we followed the way in which their concentration varies in pasteurized milk. In parallel, we analyzed the peroxidation of lipid in milk, by determining the concentration of malonyl-dialdehyde (MDA).

\section{MATERIALS AND METHODS}

Milk samples: The determinations were performed on fresh milk goats (originated from a private dairy company, from Cluj County), having 12 samples collected over the period of two weeks. An aliquot of each sample was subjected to pasteurization, thus resulting 12 parallel fresh and pasteurized samples. Milk samples were stored in a refrigerator, at $4^{\circ} \mathrm{C}$, until analysis (for about 2 hours).

Enzymatic assays: In order to determine the activity of lactoperoxidase, we used a kinetic method with ABTS - 2,2'-azino-bis(3ethylbenzothiazoline-6-sulphonic acid) (Kumar and Bhatia, 1999; Pintea et al., 2008). Glutathione peroxidase activity in milk samples was performed on skimmed milk, using a commercial kit (Ransel, Randox Laboratories) and a semiautomatic biochemistry analyzer MasterPlus Screen. The final results were reported in units per $\mathrm{ml}$ of milk (Andrei et al., 2011).

Determination of vitamins $\mathbf{A}$ and $\mathbf{E}$ was performed by HPLC chromatography on the extracts obtained from milk samples. To perform quantitative analysis in a first stage, calibration curves were determined (calibration curves), using standard solutions (Sigma) of trans-total retinol (concentrations between 5-100 $\mu \mathrm{g} / \mathrm{ml}$ ) and standard solutions (ChromaDex, USA) of a-tocopherol (concentrations between $4-50 \mu \mathrm{g} /$ $\mathrm{ml})$. The retinol standard solutions and extracts obtained from milk were injected into an HPLC system equipped with pumps Shimadzu LC-20 AT, a detector with photodiode SPD-M20A, a Rheodyne injector with $20 \mu \mathrm{l}$ loop and a column Hibar 250-4 Lichrosorb RP18 (25 cm x $4.6 \mathrm{~mm}$ and particle size of $5 \mu \mathrm{m}$ ). The mobile phase consisted of acetonitrile: methanol 85:15, in isocratic system (Andrei et al., 2009). Tocopherol standard solutions and extracts obtained from milk were injected into an HPLC system equipped with pumps Shimadzu LC-20 AT, a RF20A fluorescence detector at excitation wavelength of $290 \mathrm{~nm}$ and emission $330 \mathrm{~nm}$ and a column Lichrosorb Si60 $250 \times 4.6 \mathrm{~mm} ; 5 \mu \mathrm{m}$. Mobile phase consisted of acetonitrile: hexane: 2-propanol (99.5:0.5; v/v), in isocratic system.

Determination of vitamins C: Under the action of oxidants, ascorbic acid becomes dehydroascorbic acid. The oxidizing agent that is frequently used is 2,3-diclorfenolindofenolul, colored in red, which by reduction (acceptance of hydrogen yielded vitamin C) turns in leucoderivat (Pintea et al., 2008).

Caseins assay: The first step in this analysis consisted in removing lipids from milk (centrifuging the milk at $5000 \mathrm{rpm}$, for $1 \mathrm{~h}$, at $4^{\circ} \mathrm{C}$ ), followed by caseins dissociation. Total protein content was determined using the Bradford method (Pintea et al., 2008; Andrei et al., 2011). In the second step, caseins were precipitated by treating milk with $1 \mathrm{M} \mathrm{HCl}$ to $\mathrm{pH} 4.6$, after which samples were centrifuged for 20 minutes at 5,000 $\mathrm{rpm}$. Whey, representing the upper aqueous phase, was collected and protein concentration was determined using the same photometric method. By difference between total protein and soluble protein (from whey), the concentration of caseins was calculated.

Lipids peroxidation level. For quantitative determination of the MDA, a photometric method with thiobarbituric acid was used (Pintea et al., 2008; Andrei et al., 2009). The results were expressed in nmol MDA $/ \mathrm{ml}$ milk.

Statistical analyses: The comparative interpretation of variables (normal milk vs. pasteurized milk) was performed using modified Welch $\mathrm{T}$ test (ANOVA), with the expression index of probability ("p"). Differences were considered significant at a $\mathrm{p}$ value between $0.05-0.01$ marked with *, very significant at a p value between 0.01-0.001 marked with ${ }^{* *}$ and extremly significant at a p value lower de 0.001 marked with ${ }^{* * *}$.

\section{RESULTS AND DISCUSSION}

The results obtained in the analysis of the activity of antioxidant enzymes LPx respective GPx (minimum and maximum values, mean values and standard deviation) for all normal and pasteurized milk samples are presented in Table 1.

Lactoperoxidase (LPX) is one of the most abundant milk enzymes, representing approximately $0.5 \%$ of total soluble protein and $0.1 \%$ of 
the total milk protein. In the case of pasteurized milk, the enzyme looses much of its activity, showing lower values than raw milk ( $p=0.00367$; very significant). The data obtained are consistent with those presented by Raynal-Ljutovac et al. (2007), according to which milk enzymes are denatured during heat treatment. The percentage of distortion is dependent on temperature, heating time and the type of enzyme. According to data presented by Stepaniak (2004), heat can cause significant changes to the enzymatic equipment of milk, causing a moderate inactivation of lactoperoxidase.

In the case of pasteurized goat's milk, there is a decrease in GPx activity compared to normal milk ( $\mathrm{p}=0.00381$; very significant). According to data presented by Lindmark-Maensson and Aekesson (2000), this enzyme does not appear in the milk in free form, but as a complex format with high molecular weight caseins.

The most important vitamins present in milk are vitamin E (tocopherol) and vitamin A (retinol). The presence of these vitamins in milk is important, because it protects the body against oxidative stress and is essential for normal development of the body, as well as the proper functioning of the immune system (Debier et al., 2005).
As it can be seen from Table 2, pasteurization causes a reduction in milk retinol concentrations ( $p=0.000219$; extremely significant).

Our data is consistent with those reported by Whiten et al. (2002), according to which there are two major factors that causes a decrease in the concentration of vitamin A in milk: light exposure and temperature factors that determine enhanced formation of active oxygen species, species that are inactivated by this antioxidant vitamin. By exercising this function, retinol is oxidized, resulting in decreased concentrations in milk. In addition, Noziere et al. (2006) have shown that the thermal processing of milk causes a decrease in retinol concentrations because, in the pasteurization process, retinol isomeration also occurs (from the trans to the cis form), and this isomerization is directly dependent on the intensity of the heat treatment.

The concentration of vitamin $\mathrm{E}$ in the membranes of the fat globules may be used as a measure of the oxidative stability of milk (Fox et al., 2006). The pasteurization of milk also affects the concentration of vitamin $\mathrm{E}$. In the case of tocopherols, the decrease is not as accentuated, compared to that recorded in the case of retinol ( $p$ $=0.00025$; extremely significant). Thus, according to the data obtained by us, pasteurization causes

Tab.1. The activity of antioxidant enzymes in raw and pasteurized milk samples $(n=12)$

\begin{tabular}{ccccc}
\hline & \multicolumn{2}{c}{$\mathrm{LPx}(\mathrm{U} / \mathrm{ml})$} & \multicolumn{2}{c}{$\mathrm{GPx}(\mathrm{U} / \mathrm{ml})$} \\
\cline { 2 - 5 } & raw milk & pasteurized milk & raw milk & pasteurized milk \\
\hline minimum & 0,98 & 0,28 & 18,52 & 8,45 \\
\hline maximum & 3,45 & 2,01 & 48,23 & 20,01 \\
\hline mean & $2,0483^{* *}$ & $1,036^{* *}$ & $33,655^{* *}$ & $12,575^{* *}$ \\
\hline standard deviation & 0,977 & 0,693 & 9,163 & 3,570 \\
\hline ** $0.01<\mathrm{p}<0.001$, very significant & & & &
\end{tabular}

Tab. 2. The concentration of antioxidant vitamins in raw and pasteurized milk samples $(n=12)$

\begin{tabular}{ccccccc}
\hline & \multicolumn{2}{c}{ Retinol $(\mathrm{mg} / \mathrm{ml})$} & $\alpha$-tocopherol $(\mathrm{mg} / 100 \mathrm{ml})$ & \multicolumn{2}{c}{ Vitamin C $(\mathrm{mg} / 100 \mathrm{ml})$} \\
\cline { 2 - 7 } & raw milk & $\begin{array}{c}\text { pasteurized } \\
\text { milk }\end{array}$ & raw milk & $\begin{array}{c}\text { pasteurized } \\
\text { milk }\end{array}$ & raw milk & $\begin{array}{c}\text { pasteurized } \\
\text { milk }\end{array}$ \\
\hline minimum & 10,58 & 5,06 & 59,8 & 39,89 & 3,99 & 2,25 \\
\hline maximum & 18,95 & 12,78 & 67,1 & 50,01 & 5,57 & 3,74 \\
\hline mean & $15,775^{* * *}$ & $8,9^{* * *}$ & $62,4^{* * *}$ & $46,293^{* * *}$ & $4,921^{* *}$ & $2,935^{* *}$ \\
\hline standard deviation & 2,963 & 2,610 & 2,619 & 3,262 & 0,538 & 0,457 \\
\hline${ }^{* *} 0.01<$ p $<0.001$, very significant & & & & & &
\end{tabular}

$* * * \quad \mathrm{p}<0.001$, extremely significant 
a decrease of more than $43 \%$ of the retinol concentration, while in the case of a-tocopherol, the percentage of variation is less than approximately $25 \%$.

The content of vitamin $\mathrm{C}$ in milk varies both according to species, as well as according to nutrition. Vitamin C (Table 2) decreases in the heat-treated milk, being known that this vitamin is easily degraded in the presence of the air oxygen, light and heat $(\mathrm{p}=0.00212$; very significant). According to data presented by Gliguem and Aragon (2005) the losses of vitamin C are more important in sterilized milk, when compared with UHT milk, and increase with the storage time. Thus, in the case of sterilized milk, it was observed that the ascorbic acid concentration reaches zero after 30 days of storage, while in the case of UHT milk, concentration is reduced by about $50 \%$ after 120 days of storage.

It is well known that, in the case of cow's milk, the thermal treatment induces changes in the protein profile. For example, Considine et al. (2007) observed that the temperature induces a dissociation of the casein from the casein micelles. Dissociation of the micelles is directly proportional to the temperature and duration of the heat treatment. Thus, at a temperature higher than $70^{\circ} \mathrm{C}$, all caseins are in a dissociated state, the ratio between certain caseins being also modified.
They observed an increase of k-casein, while maintaining a constant level of b-casein.

In the present study, as shown in Table 3, a higher level of caseins appears in pasteurized goat milk, compared with fresh milk ( $p=0.00994$; significant).

In another study, conducted by Nabhan et al. (2004), the combined effect of high temperature and pressure on milk proteins was followed. They noted that the combination of temperature with high pressure causes the formation of polymers between caseins and soluble proteins. Thus, almost half of the amount of b-lactoglobulin forms polymers, in particular the K-casein. It also observed that, at high pressure, even if we increase the temperature, an obvious dissociation from caseins of the micelles does not occur. Changing the ratio of caseins and whey proteins, particularly of the b-lactoglobulins / caseins, as a result of temperature increase were observed in the study published by Raynal-Ljutovac et al. (2007). The increase of this ratio can be explained by either reducing the content of soluble protein, or by increasing the concentration of caseins.

The decrease in the antioxidant activity of the milk after pasteurization results in an increase in the concentration of products formed by oxidative degradation of lipids. Determination of lipid peroxidation was carried out by monitoring

Tab. 3. The concentration of caseins into raw and pasteurized milk $(n=12)$

\begin{tabular}{ccc}
\hline & \multicolumn{2}{c}{ Caseins $(\mathrm{mg} / 100 \mathrm{ml})$} \\
\cline { 2 - 3 } & Raw milk & Pasteurized milk \\
\hline minimum & 23,97 & 29,89 \\
\hline maximum & 28,74 & 35,64 \\
\hline mean & $26,265^{*}$ & $32,023^{*}$ \\
\hline standard deviation & 1,691 & 1,987 \\
\hline $0.05<\mathrm{p}<0.01$, significant & &
\end{tabular}

Tab. 4. The concentration of malonyl dialdehyde (MDA) into raw and pasteurized milk $(\mathrm{n}=12)$

\begin{tabular}{ccc}
\hline & \multicolumn{2}{c}{ MDA (nmoli / ml ) } \\
\cline { 2 - 3 } & Raw milk & Pasteurized milk \\
\hline minimum & 13,18 & 18,58 \\
\hline maximum & 19,02 & 25,14 \\
\hline mean & $14,901^{* *}$ & $21,268^{* *}$ \\
\hline standard deviation & 2,008 & 2,145 \\
\hline$* 01<p<0.001$, very significant & &
\end{tabular}


the malonyl-dialdehyde concentration, the results being presented in Table 4.

The data obtained in this work confirms the results obtained by Calligaris et al. (2004), demonstrating that different heat treatments of the milk leads to increased levels of lipid peroxidation ( $p=0.00319$; very significant). They explain this change based on the fact that, during thermal processing, there is an increase in oxidative degradation of antioxidant molecules of milk (fat-soluble antioxidants in particular), and can no longer protect the unsaturated fatty acids of the lipid components.

\section{CONCLUSION}

The data presented above shows that there is a direct relationship between pasteurization, the decrease in the concentration of antioxidants and the increase of lipid peroxidation. In the case of pasteurized milk, studied antioxidant enzymes lose their activity, but are not completely inactivated. The process of pasteurization leads to a decrease of about $50 \%$ in the activity of the enzymes. Pasteurization leads to a decrease of more than $43 \%$ of the retinol concentration, while in the case of a-tocopherol, the percentage of variation is smaller, approximately $25 \%$. The content of vitamin $\mathrm{C}$ decreases in heat-treated milk, knowing that this vitamin is easy degraded in the presence of oxygen from air, light and heat.

Increasing the temperature causes a dissociation of casein micelles caseins, which leads to an increase in free total caseins.

\section{REFERENCES}

1. Andrei S, Groza IS (2010). Fiziologia si patologia glandei mamare la vaca. AcademicPres, Cluj-Napoca.

2. Andrei S, Matei S, Fit N, Cernea C, Ciupe S, Bogdan S, Groza IS (2011). Glutathione peroxidase activity and its relationship with somatic cell count, number of colony forming units and proteins content in subclinical mastitis cows milk. Romanian Biotechnological 16(3):6209-6217.

3. Andrei S, Pintea A, Bunea A, Groza IS, Matei S, Ciupe S, Crainic D (2009). Non- enzymatic antioxidants concentration and lipids peroxidation level in milk from cows with subclinical mastitis. Bulletin USAMV series Veterinary Medicine 66(1):196-202.

4. Banu C, Păsat G, Dorin S, Darabă A (2007). Valorificarea laptelui de capră. Ghid practic pentru fermieri, Seria Ghiduri practice, AGIR, București, 83, 64-65,68-74.

5. Calligaris S, Manzocco L, Anese M, Nicoli MC (2004). Effect of heat-treatment on the antioxidant and prooxidant activity of milk. International Dairy Journal 14:421-427.

6. Considine T, Patel HA, Anema S, Singh H, Creamer LK (2007). Interactions of milk proteins during heat and high hydrostatic pressure treatments - A Review. Innovative Food Science and Emerging Technologies 8:1-23.

7. Debier C, Pottier J, Goffe CH, Larondelle Y (2005). Present knowledge and unexpected behaviours of vitamins A and E in colostrum and milk. Livestock Production Science 98: 135-147.

8. Fox P, Kelly $A(2006)$. Indigenous enzymes in milk: Overview and historical aspects- Part 1. International Dairy Journal16:500-516.

9. Gliguem H, Birlouez-Aragon I (2005). Effects of Sterilization, Packaging, and Storage on Vitamin C Degradation, Protein Denaturation and Glycation in Fortified Milks. J Dairy Sci 88:891-899.

10. Kumar R, Bhatia K L (1999). Standardization of method for lactoperoxidase assay in milk. Lait 79:269-274.

11. Lindmark-Maensson H, Aekesson B (2000). Antioxidative factors in milk. British Journal of Nutrition 84(1): S103-S110.

12. Nabhan M A, Girardet M, Campagna S, Gaillard L, LE Roux Y (2004). Isolation and Characterization of Copolymers of $\beta$-Lactoglobulin, $\alpha$-Lac-talbumin, $\kappa$-Casein, and $\alpha$ s1- Casein Generated by Pressurization and Thermal Treatment of Raw Milk. J Dairy Sci 87:3614-3622.

13. Noziere P, Graulet B, Lucas A, Martin B,Grolier P, Doreau M (2006). Carotenoids for ruminants: From forages to dairy products. Animal Feed Science and Technology 131:418450.

14. Pintea A, Andrei S, Bele C (2008) Biochimie Medical veterinară - lucrari practice. AcademicPres, Cluj-Napoca.

15. Raynal-Ljutovac K, Lagriffoul G, Paccard P, Guillet I, Chilliard Y (2008). Composition of goat and sheep milk products: An update. Small Ruminant Research, 60.

16. Stepaniak L (2004). Dairy enzymology. International Journal of Dairy Technology 57(2/3).

17. Whited L J, Hammond B H, Chapman K W, Boor K (2002). Vitamin A Degradation and Light-Oxidized Flavor Defects in Milk. J Dairy Sci 85:351-354. 